\title{
Emergency School Learning Model with Disaster Management in Post-Earthquake Areas in Palu City
}

\author{
Normawati ${ }^{1}$, Muhammad Rizal Masdul ${ }^{2}$, Mansur $^{3}$, Nuranisa $^{4}$ \\ \{normawati96@yahoo.com¹,rizal.masdul@gmail.com²,mansur20jan@gmail.com³, \\ nonaanisa51@gmail.com ${ }^{4}$ \}
}

Faculty of Islamic Religion, Islamic Education, Universitas Muhammadiyah Palu, Central Sulawesi 94118, Indonesia

\begin{abstract}
This research intends to: First, develop the learning of early detection and disaster risk integrated into subjects in elementary schools in disaster areas. Second, design teaching and learning strategies through a fun learning approach to increase mental resilience and learning motivation students post the disaster. Third, develop simulation learning media (audiovisual) that are recreational for students in disaster areas. The research and development with a spiral model that adapts the five phases of instructional design. The population was all elementary school students in post-disaster areas in Palu City. The sample was taken through stratified random sampling that selected two elementary schools, each of which is located in areas with the potential for tectonic earthquakes in Palu City, namely SDN Balaroa and SDN Petobo, the red zone prone to earthquakes and have the potential to be affected by liquefaction. The results of the research have been able to develop learning tools as follows; (1) special practicum kits, (2) lesson plans, (3) student activity sheets (LKS), and (4) evaluation instruments. Students have examined these learning tools at SDN Balaroa and SDN Petobo. This is following the specific objectives of this research to produce fun learning based on learning modules and develop teaching and learning strategies with a fun learning approach, to increase mental resilience and learning motivation to post-disaster students, which is then accompanied by the realization of the research objectives, namely, developing the learning of early detection and disaster risk integrated into science subjects in primary schools in disaster areas.
\end{abstract}

Keywords: Learning Model, Fun learning approach, and post-disaster learning

\section{Introduction}

Indonesia is a country rich in natural resources. However, behind this wealth, Indonesia is a disaster storefront. Following their geographic conditions, almost all regions in Indonesia are in risky areas for natural disasters. This means that disaster preparedness is urgently needed. Disaster often occurs in recent years and is no longer a foreign word to us. Almost every season, even every month, their disaster occur. The definition of tragedy varies. According to Setyowati, disaster is an activity impact or risk that harms humans [1].

One of the impacts is very much felt in the field of education. Students experience difficulties both mentally, psychologically, and physically with the destruction or damage of school learning facilities. Disasters also often have lasting consequences for children. The 
destruction of educational infrastructure due to the disaster caused the lost opportunity for children to participate in educational activities. Educational activities were then held in emergency schools. This condition lasts a long time in many disastrous events. This situation is less favourable for children who have to study with limited facilities, which in the end, the teaching and learning process cannot take place optimally.

The legal framework for overcoming this has been mandated in the 1945 Constitution Article 31 paragraph 1 . It states that every citizen has the same opportunity to obtain an education. Likewise, in the National Education System Law Number 20 of 2003, the eleventh part of article 32 states about the government's obligation to provide special education for those who experience learning difficulties, especially after a general disaster and in disadvantaged areas in particular [2]. It is deemed necessary to prepare a disaster preparedness method in an emergency school that emphasizes an interesting learning approach in terms of affective cognitive and psychomotor. This is an effort to rehabilitate students' psychological conditions. Considering emergency conditions where many learning tools were damaged, a simple, attractive learning media was created, specifically for handling education in postdisaster areas.

This research intends to introduce students to situations and problems that occur before and post-disaster; therefore, they are expected to learn to survive, accept, and face it. The researcher is interested in taking the Emergency School Learning Model theme through Fun Learning Approach in Problems were diagnosed for the first time to determine issues in the learning process post-natural disaster in emergency schools. The initial hypotheses of problems that exist post-natural tragedy are based on this research results when the researcher visits areas affected by the earthquake and regions after the earthquake and liquefaction in Palu City.

Data were collected through discussions with teachers and school authorities. Their hypothesis is: How is Emergency School Learning in post-disaster areas, especially disadvantaged areas through a Fun Learning Approach in Post-Disaster Areas?. This research's general purpose is a practical effort to evaluate the sustainability of education during disaster emergency response and disadvantaged areas for children in post-disaster schools.

The specific objectives of this research are: To motivate students who lived in post-disaster areas, especially disadvantaged areas, to keep learning even in post-disaster situations. To Evaluate the sustainability of the teaching and learning process (education) with a variety of methods, approaches, and learning media that can improve mental resilience and motivation to learn post-disaster both in terms of knowledge, attitudes, and skills. Practically this research intends to help the emergency school learning model with a fun learning approach in postdisaster areas

Previous research discusses Learning Models in Emergency Schools for Mount Merapi Disaster Victims in Sleman Regency, Yogyakarta Special Province. The catastrophic eruption of Mount Merapi on the border of Central Java Province and Yogyakarta Special Region is a natural occurrence that has resulted in the destruction of various public facilities and infrastructure including schools [3] . There is also research on post-disaster emergency classes 
for elementary students by offering the concept of non-formal education. It consists of two modules, namely the classroom module, which accommodates teaching and learning functions, and multimedia fun learning [4]

\section{Method}

This qualitative research produces descriptive data in the form of writing about people or people's words and their visible behavior. The use of this method is seen as a "research procedure" that is expected to produce descriptive data in the form of written or spoken words from a number of people and observed their behaviour [5]. Qualitative research methods are often called natural research methods because the research is carried out in natural conditions (natural setting); it is also called the ethnographic approach because initially this method is more widely used for research in the field of cultural anthropology; referred to as a qualitative method because the data collection and data analysis are more of a qualitative nature [6].

This research was conducted in an emergency school located in Palu City, Central Sulawesi Province, in the areas affected by the Earthquake, Liquefaction, and Tsunami on September 28, 2018.

\section{Results and Discussion}

\subsection{General Description of Refugee Areas}

The earthquake occurred forced all residents in disaster areas to evacuate to a safer place. Many children of school age move with their parents or family. In addition, many children lost their parents and families, so they try to save themselves to a safer place. Children have to bear a heavy psychological burden in an effort to save themselves from the threat of disaster and heavy-duty of life due to the loss of their family and loved ones; this causes them not willing to participate in learning activities at refugee camps. In this connection, various efforts by adults are needed to motivate children, and they are expected to be more passionate about carrying out daily activities, including learning activities.

The government in Palu city conveys the message to parents in refugee areas to keep their children studying according to their education level. The government organized emergency schools located at SDN Balaroa and SDN Petobo located close in order for the learning activities to be conducted. In a book of "Disaster Management"[7]. Pevention activities are divided into 2, namely: First is prevention in passive mitigation. This activity includes drafting laws and regulations, making disaster-risk maps and mapping problems, making procedure guidelines, conducting research related to disasters, assessment, disaster risk analysis, the establishment of disaster response organizations and strengthening social units in the community, and prevention in active mitigation. 
These activities include the creation and placement of danger warning signs, the prohibition of entering disaster-risk areas, monitoring the implementation of various spatial planning regulations, relocating residents from disaster-risk areas to safer places, creating evacuation routes, and build structures in accordance with the established building standards. Second, disaster preparedness can be defined as a state of readiness in the face of a crisis. Preparedness can be carried out by pro-active activities in planning actions to respond to disasters. The International of Red Cross and Red Crescent Society (IFRC) explains that preparedness is a continuous and integrated process resulting from a variety of risk and resource reduction activities. Disaster preparedness provides a program to design practical, realistic, and coordinated plans with risk reduction measures, prevent disaster situations, save maximum lives and return the community back to normal functions in a short time [8].

Disaster response is an activity during a disaster that involves multi-agency coordination in responding to disasters. This activity is held to reduce the impact of disasters. Activities in disaster response include quickly studying the location, damage, and resources, determining the status of a disaster emergency, providing emergency health services and evacuating or rescuing people affected by disasters, meeting basic needs, and protecting vulnerable groupsfourth; Recovery (Recovery). The Asian Disaster Preparedness Center (ADPC) explained that recovery is an activity after emergency needs have been met, and the initial crisis ends. Important components during the recovery process include agreement on institutional arrangements, coordination, and communication between institutions, monitoring, and evaluation until conditions in the surrounding community return to normal in long-term development project planning. This activity can be supported by conducting an assessment of the needs of the affected communities prior to the development project. The stages in the recovery phase are divided into two stages, namely as follows.

The first stage is Rehabilitation. Recovery is to improve the condition of the affected area, which is uncertain to a better normal state. Therefore people's lives can return to normal. These activities can be carried out through rebuilding the disaster area, repairing public facilities and infrastructure, providing assistance to repair houses in the community, sociopsychological recovery, continued health care, conflict resolution, socio-economic and cultural healing, as well as restoration of security and order.

The second stage is Reconstruction: Reconstruction is the stage of rebuilding facilities and infrastructure damaged by the disaster. Activities carried out at the reconstruction stage are the reconstruction of facilities and infrastructure, reconstruction of community social facilities, restoring the life of the socio-cultural community, using good designs and disaster-resistant equipment, improving public service functions, and improving essential services in the community. This activity should be carried out through planning, preceded by an assessment of various experts and sectors related to the findings of the meeting. This is indicated by decreasing low values (1 and 2) and increasing high scores (4 and 5).

\subsection{Emergency School}

SDN Balaroa, as an emergency school, has a reasonably large location. Apart from the principal's room, the teacher's room, the principal's official residence, and 12 classrooms, SDN 
Pangukan also has a hall, an art room, a library room, and a prayer room. With the availability of various room facilities at SDN Balaroa, in general, the policy of organizing this emergency school does not interfere with the teaching and learning activities of regular SDN Balaroa students because they can still study as usual by occupying their respective classrooms. Meanwhile, the learning space for refugee children in the library, art room, hall, prayer room, and the terrace of SDN Balaroa.

\subsection{Students}

There were 208 children who participated in the learning activities in the emergency school, consisting of 107 boys and 101 girls-parents and children who took refuge in various areas of Palu city, which are safe areas from disasters.

\subsection{Infrastructure}

Facilities and infrastructure owned by the emergency schools at SDN Balaroa and SDN Petobo are quite adequate compared to emergency schools located in tents or other evacuation locations. This is because SDN Balaroa and SDN Petobo themselves have sufficient facilities and infrastructure; this meets their needs for learning activities; facilities available are excellent and comfortable buildings, tables and chairs, blackboards, chalk, erasers. , library books, and mats. In order to fulfill adequate facilities and infrastructure, the locations of SDN Balaroa and SDN Petobo are easily accessible by public transportation; it more comfortable to distribute assistance for learning activities such as elementary school uniforms, learning resources, learning media, and their utilization facilities and stationery.

Many institutions have participated in the implementation of emergency schools, both government and private institutions, such as the Indonesian Ministry of Education and Culture and the Palu branch of the Indonesian Red Cross (PMI). Many assistance was provided, material, and non-material. At the handover and signing event, the learning media assistance from the Head of the Palu City Education, Youth and Sports Office responded because it was beneficial and it motivates students to participate in learning activities in emergency schools. Furthermore, the Head of the Education Office emphasized that the volunteer teacher's level up the use of available learning media [9].

The existence of transition schools is an option to accelerate education recovery in Central Sulawesi post-disaster on September 28, 2018. The semi-permanent school building can be used for teaching and learning activities while awaiting the rebuilding of a permanent school building by the government during the Rehabilitation and Reconstruction of Central Sulawesi for the next two years.

Edhie Sarwono, Director of United Tractors, in his statement to journalists after the closing ceremony of the United Tractors Group Humanitarian Program for Palu, Sigi, and Donggala, said that the transitional school building facilities are expected to accelerate the recovery of education in Central Sulawesi. He said the transitional school building can be used for teaching and learning activities within two years while waiting for the construction of a permanent school construct by the government [10]. Ten schools they build support 155 educators and 1,025 students. We want more, but in the meantime, that is what the best. 
Furthermore, many students can be covered to recover their enthusiasm to gain knowledge and build better character, "he explained.

Marlina Aliman, the principal of SDN 1 Petobo, told VOA that even though it is not a permanent school, the construction of a transitional primary school is significant for teachers and students who have spent a long time studying in an emergency tent. Before United Tractors' assistance, we learned from the emergency tents provided by the Ministry of Education and Culture. We studied there. There were five schools in one tent, consisting of three public schools and two private schools. Marlina, from SDN 1 Petobo, was affected by liquefaction in the earthquake on September 28, 2018. Besides that, one teacher and seven students died in the incident. She said that for a long time, teaching and learning activities had to be conducted in emergency tents. He reported that after the disaster, the number of students at his school, which previously only 232, had decreased to 162 students. According to him, this was because many children go to the shelter with their parents. He hopes that during the rehabilitation and reconstruction period of Central Sulawesi after the natural disaster, which lasted for two years, the government can provide land for the reconstruction of permanent school buildings. Marlina, The most important thing from the government is to prepare a location to build a permanent school because until now they are still carrying out teaching and learning activities in emergency schools and really expect the government's attention to build a permanent school as soon as possible, so that the learning process will run smoothly again.

Ansar Sutiadi, Head of the Education and Culture Office of Palu City, said that his party had made efforts to make improvements in elementary and junior high school (SMP) buildings involving support from the Ministry of Education and Culture, NGOs, and the private sector which for now is prioritizing badly damaged schools. He said that the general repair of school buildings that were heavily, moderately, and lightly damaged in Palu City would take two years. According to Ansyar Sutiadi, repairs due to the damage have begun to be repaired, assistance from the Ministry of Education and Culture, assistance from NGOs, assistance from the private sector, others are still waiting, but we will prioritize schools that are badly affected and are targeted for completion of 2 years. Ansar Sutiadi added that currently, 15 transitional or semi-permanent schools had been built in affected areas such as in Balaroa and Petobo. Hopefully, all children may attend school. Even though the facilities are still minimal, at least teaching and learning activities have been held in these transition schools.

\subsection{Learning Management in Emergency School}

Learning activities in emergency schools are the same as learning activities held in traditional schools in general, except for the total learning time, which lasts 3 (three) hours (starting at 07.00-10.00 WITA). Even though volunteer teachers are urged to continue learning activities according to the schedule and time allocation in schools in general, in practice, students are already tired of attending lessons when the time is late due to the scorching conditions in the emergency school.

Students argued that every night the atmosphere in the evacuation area was boisterous. It disturbs their rest time. Therefore, every 10.00 WITA, they start to feel sleepy, so they ask that 
the learning activity should be ended. Thus, volunteer teachers were forced to end learning activities at 10.00 WITA.

According to the volunteer teachers who were respondents, at first, it was difficult for refugee children to attend school. The volunteer teachers patiently persuaded the children to go to school to study. Even further, they pick them up and coax them at the refugee camp every morning. Thanks to the patience and persistence of the volunteer teachers, the students gradually showed changes and began to be inspired to attend emergency schools regularly. Changes in the attitudes of students started to appear when students took part in learning activities that use learning media (A.M, 2016)

Teachers are equipped with knowledge and skills and learning media to manage learning activities in emergency schools. The literal meaning of media is the plural form of the word médium. Media is an intermediary or introduction, in other words, namely as an intermediary that delivers information between the source and the recipient [11].

The use of instructional media is one of the alternative solutions to overcome the difficulties/limitations of implementing learning activities because one of the main functions of learning media is as a teaching aid that also influences the climatic conditions and learning environment that are arranged and created by the teacher [12]. It is further argued that the use of instructional media in the teaching and learning process can generate new desires and interests, generate motivation and stimulation of learning activities, and even bring psychological influences on students. One form or type of learning media is Video Compact Disk (VCD). The definition of VCD is a digital standard format for storing video on a compact disc (compact disc). VCD are types of digital optical discs that are used to store data and are portable or can be carried anywhere [13] .

The volunteer teachers no longer fully use the lecture method but learning media. After completing the use of learning media, the volunteer teacher (a) provides additional explanations, (b) provides opportunities for students to ask questions or express their opinions on the subject matter that is broadcast through learning VCD media, (c) organize discussion activities. At last, volunteer teachers provide questions about the subject matter discussed to be worked on but only when time is available,

Students are grouped according to their level or class and accompanied by two volunteer teachers. Volunteer teachers who teach in emergency schools are assigned by the Palu City Youth and Sports Education Office. Each elementary school in Palu City that is not affected by the earthquake and liquefaction is required to send one volunteer teacher to teach at an emergency school. Thus, volunteer teachers are basically teachers who teach in regular schools who are temporarily assigned to teach in emergency schools.

\subsection{Learning Model in Emergency School}

\subsubsection{Changes in Student Behaviour during Learning Activities}

The unavailability of books in emergency schools is not an obstacle because learning media and media presentation equipment is used, teachers can display subject matter derived from electronic school books (BSE) and learning videos containing subject matter for 
elementary students. Students are brought to know the environment, interact, identify objects in the form of images with uniformity of observation so that children can arise new desires and interests, and are motivated to keep learning. [14] .

Children begin to show feelings of motivation and pleasure to go to school to participate in learning activities due to VCD's use as learning media. Even children who feel they only provided less time to take part in learning activities as they think interested and happy with the learning videos. Changes in children's attitudes that occur can be due to the impact/influence of the used learning media, which has been proven to have several potentials and strengths.

Each student's experience is different, depending on the factors that determine the richness of his experiences, such as the availability of books that can be easily reached and the family or community environment who likes to read. Learning media can overcome various limitations exist. Multiple objects that are difficult to show to students to be discussed/studied can be packaged, either in a tangible form, miniature, models, or in the form of images and can be presented in audiovisual format.

There are many objects that students cannot experience directly in the classroom, among others, because: (a) the thing is too big; (b) the item is too small; (c) the object is moving too slowly; (d) the thing is moving too fast; (e) the object is too complicated; (f) the item sounds too delicate, or (f) dangerous objects with high risk. All of these objects can be presented to learners through the use of appropriate media. The benefits obtained from these activities are:

Allow direct interaction between students and their environment.

It is generating uniformity of observations.

It is embedding basic concepts that are correct, concrete, and realistic.

They are generating new desires and interests.

Generating motivation and stimulating children to learn.

Providing an integral/comprehensive experience from the concrete to the abstract

The behavior of students from unwilling at the beginning or less interested in coming to the emergency school, and even having to be persuaded and invited now change into students who are motivated to study in emergency schools at SDN Balaroa and SDN Petobo. The changes shown by these students were seen after they participated in learning activities using learning media. $36(90 \%)$ of students stated that they were happy with learning activities using teaching media. They said the subject presented was interesting, not dull, and straightforward, so it is easier to understand. Only $8(20 \%)$ students said they did not like learning activities through learning media because the presentation and explanation of subject matter are fast that they cannot fully follow or understand.

\subsubsection{Benefits of the application of learning activities using VCD as learning media}

The Pustekkom Kemdikbud not only provides learning media in the form of electronic school books (BSE), learning VCDs for mathematics, Natural Sciences, Social Sciences, Indonesian Language, and some general skills CVD and general knowledge as stated before, but also VCD of learning educational cartoons which contain a collection of light stories that are entertaining along with their utilization facilities. This academic cartoon learning VCD is used during rest time. Thus, students who come to emergency schools learn about the subject 
matter, but they can also enjoy entertainment (learning through entertainment) provided during recess hours.

The volunteer teachers who were respondents, on the other hand, stated that the availability of instructional media along with its utilization facilities in emergency schools is beneficial for them to manage learning activities. It is further argued that the subject presented through learning media is packaged in an attractive, straightforward, and easy to understand manner. Whenever it is needed, or certain parts of the subject matter are still not difficult to understand, the learning media can be played/used repeatedly. Furthermore, students stated that they had never participated in learning activities that use VCDs at their respective home schools because their original schools did not yet have learning VCDs and the facilities that can be used. This is their new experience.

Most of the 32 students ( $80 \%$ ) stated that they could understand the subject easily if it is presented using learning media. Only $8(20 \%)$ indicated that they felt somewhat challenging to understand the subject matter shown through the use of teaching media because they are required to participate in learning activities seriously. Particularly with the subject matter for grade VI, it was stated by the respondents that they preferred science and mathematics Bahasa Indonesia because Bahasa Indonesia subject is not as tricky as science and mathematics.

\section{Conclusion}

The results of the research can develop learning tools such as; (1) special practicum kits, (2) lesson plans, (3) student activity sheets (LKS), and (4) evaluation instruments. These learning tools have been tested on students at SDN Balaroa and SDN Petobo. This is in accordance with the specific objectives of this research related to the goals of producing fun learning-based learning modules and developing teaching and learning strategies with a fun learning approach. In an effort to increase mental resilience and learning motivation of postdisaster students, the research objectives provided, namely, developing learning about early detection and disaster risk integrated into science subjects in primary schools located in disaster areas. Thus this design can be implemented in accordance with the objectives, namely, developing teaching and learning strategy with a fun learning approach to increase mental resilience and student motivation post-disaster in that is line with the realization of the first research objectives, namely, developing learning about early detection and risk of disasters integrated into science subjects in primary schools in disaster areas.

Learning tools are successfully developed and support the quality of the process and quality of science teaching and learning outcomes. Student activity is dominated by activities using learning tools, field practice, relevant discussions, and activities to practice operational independence that increase along with the high percentage of teacher activity in training these skills to students. Functional independence that is dominantly carried out by students is the skill of observing and sharing tasks in groups to complete group tasks. Students said they were happy with these new learning tools and models developed by researchers; therefore, students were interested in taking part in the next science learning as they had been following. The 
teacher considers the learning media that the researcher has developed quite helpful and very useful in the science teaching and learning process. However, it still takes quite a long time to improve the achievement of that goal because the central concept "fun learning" can only be achieved through continuous development and improved in the following year.

\section{References}

[1] D. S. Liesnoor, Pendidikan Kebencanaan (Bencana Banjir, Longsor, Gempa dan Tsunami). Buku Referensi,. Semarang: CV Sanggar Krida Aditama., 2017.

[2] D. Gogot Suharwoto, Nurwin, "Modul Manajemen Bencana Di Sekolah,” pp. 1-101, 2015.

[3] Innayah, "Model Pembelajaran Di Sekolah Darurat Korban Bencana Gunung Merapi Di Kabupaten Sleman, Propinsi Daerah Istimewa Yogyakarta,” J. Teknodik, vol. Vol. XV, pp. 4960, 2011

[4] F. Rusvidianti and T. Indrojarwo, "Desain Kelas Darurat Pasca Bencana untuk Sekolah Dasar di Indonesia," vol. 4, no. 2, pp. 2-5, 2015.

[5] Emzir, Metodologi Penelitian Pendidikan. Jakarta: RajaGrafindo Persada, 2013.

[6] Sugiyono, Metode penelitian Kuantitatif, Kualitatif dan R\&D. Bandung: Alfabeta, 2017.

[7] R. S. Nurjanah, Manajemen Bencana. Yogyakarta: Alfabeta, 2013.

[8] Bevaola Kusumasari, Manajemen bencana dan kapabilitas Pemerintah Lokal. Yogyakarta: Penerbit Gava Media, 2014.

[9] S. Gatra, "Kemendikbud Identifikasi Sekolah Rusak di Palu dan Donggala," Kompas.com, 2018. .

[10] Y. Litha, "Sekolah Transisi, Bantuan Percepatan Pemulihan Pendidikan di Sulteng," VOA Indonesia, 2019. .

[11] A. S. Sadiman, Media Pendidikan Pengertian, Pengembangan dan Pemanfaatannya. Jakarta: P. T. Raja Grafindo Persada, 2014.

[12] A. Arsyad, Media pembelajaran. Jakarta: PT Raja Grafindo Persada, 2014.

[13] Ames Boston, "Pengertian dan Perbedaan CD, VCD dan DVD," 2020. .

[14] Abdulhak, Teknologi Pendidikan. Bandung: Remaja Rosdakarya, 2013. 